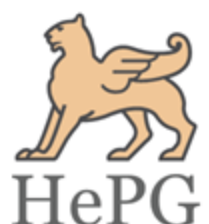

ISSN: 2348-1900

Plant Science Today

http://www.plantsciencetoday.online

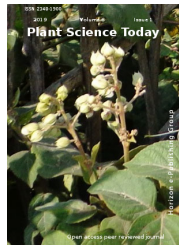

Research Article

\title{
Genus Athyrium Roth (Athyriaceae: Pteridophyta) from Gujarat State
}

\author{
Ronak N Kachhiyapatel, Sachin M Patil, Vinay M Raole and Kishore S Rajput ${ }^{*}$ \\ Department of Botany, Faculty of Science, The Maharaja Sayajirao University of Baroda, Vadodara 390 002, India
}

\section{Article history}

Received: 30 December 2018

Accepted: 23 January 2019

Published: 01 February 2019

\section{Editor}

Salanta Liana-Claudia

University of Agricultural

Sciences and Veterinary

Medicine of Cluj-Napoca

(USAMVCN)

Romania

\section{Publisher}

Horizon e-Publishing Group

\author{
*Correspondence \\ Kishore S. Rajput \\ 䎿.rajput15@yahoo.com
}

\begin{abstract}
Present study deals with the diversity, distribution and conservation status of the genus Athyrium Roth in different climatic regimes of Gujarat state. Five species of Athyrium viz., A. hohenackerianum T. Moore, A. falcatum Bedd., A. micropterum FraserJenk., A. parasnathense (C.B.Clarke) Ching ex Mehra \& Bir and A. schimperi subsp. biserrulatum (Christ) Fraser-Jenk., were collected form the Gujarat state, of which $A$. hohenackerianum T. Moore is documented earlier. Therefore, occurrence of $A$. falcatum, A. micropterum, A. parasnathense, and A. schimperi subsp. biserrulatum, stands as a new distribution records and reported for the first time from Gujarat state. A detailed taxonomic description, photo plates, morphological characters, distribution and comparison of species is provided here for their identification.
\end{abstract}

Keywords: Gujarat; Athyriaceae; New distribution record; Athyrium

\section{Citation}

Kachhiyapatel RN, Patil SM, Raole VM, Rajput KS. Genus Athyrium Roth (Athyriaceae: Pteridophyta) from Gujarat State. Plant Science Today 2019;6(1):54-62. https://doi.org/10.14719/pst.2019.6.1.471

\begin{abstract}
Copyright: (c) Kachhiyapatel et al. (2019). This is an open-access article distributed under the terms of the Creative Commons Attribution License, which permits unrestricted use, distribution, and reproduction in any medium, provided the original author and source are credited (https://creativecommons.org/licenses/by/4.0/).
\end{abstract}

Indexing: Plant Science Today is covered by Scopus, CAS, AGRIS, CABI, Google Scholar, etc. Full list at http://www.plantsciencetoday.online

\section{Introduction}

The lady fern genus Athyrium Roth (family Athyriaceae) was originally described in 1800 (1) based on Athyrium filix-femina (L.) Roth. The Generic concept in the Athyrioid ferns is always debateable. Many genera viz. Anisocampium C. Presl (incl. Kuniwatsukia Pic. Serm.), Cornopteris Nakai (incl. Neoathyrium Ching \& Z.R. Wang) and Pseudocystopteri Ching \& Z.R. Wang were separated earlier from the genus Athyrium Roth. However, recently all these representatives are treated under a single genus Athyrium (2-6). It is one of the most diversified genera in the world, having ca. 220-230 species (7), of which ca. 50 species and 17 hybrids are reported from India (8). The pteridological studies were carried out by various researchers in the Gujarat (9-16) and a single species (i.e. A. hohenackerianum T. Moore) is reported previously from Gujarat state (17).

Since 2013, we initiated the survey for documentation of the pteridophyte diversity in the Gujarat and periodically visiting different parts of the state like wetlands, agricultural fields, hilly regions and plains. Terrestrial ferns growing naturally in shaded, semi-shaded or as a lithophyte on exposed places of rock, on mountain steeps and 
river banks. They were collected from different forests of Saurashtra, central and south Gujarat. On critical study and comparison with available literature collected specimens were identified as Athyrium falcatum Bedd., A. parasnathense (C.B.Clarke) Ching ex Mehra \& Bir, A. micropterum Fraser-Jenk., and $A$. schimperi subsp. biserrulatum (Christ) Fraser-Jenk., belonging to the family Athyriaceae. Perusals of available literature on pteridophyte diversity of Gujarat showed that occurrence of these four ferns were not documented so far in the existing list of the pteridophyte diversity of Gujarat state $(12,17,18$ 20). Therefore, a brief description and photograph (Fig. 1-4) of these four taxa are given as follow for their easy identification.

\section{Materials and Methods}

Field survey were carried out during the period of 2013-2018 from different forest areas of Gujarat. The collected specimens were pressed using field presser and processed at laboratory. These pressed specimens were poisoned by $4 \%$ formalin and affixed on the herbarium sheets by using fevicol glue. Collected specimens were identified with the help of available literature (8, 21-26). Further identity of all species of Athyrium were confirmed by comparing with the help of authentic herbarium specimens available in different herbaria, viz. MH, BSI, BLAT and SUK. The voucher specimens were deposited in herbarium of the Department of Botany, The Maharaja Sayajirao University of Baroda, Vadodara, Gujarat (BARO).

\section{Taxonomic treatment}

\section{Key to the species}

1a. Lamina pinnatifid or pinnatisect 2

1a. Lamina bipinnate or tripinnate .. 3

2a. Lamina pinnatifid, lower pinnae suddenly reduced, pinnae auriculate A. falcatum

2b. Lamina pinnatisect, pinnae gradually reduced, pinnae not auriculate A. micropterum

3a. Lamina bipinnate, densely scaly stipe and rachis A. hohenackerianum

3b. Lamina tripinnate, sparsely scaly stipe only .. 4

4a. Pinnae apex acute, margin crenate A. parasnathense

4b. Pinnae apex long acuminate, margin dentate A. schimperi subsp. biserrulatum

Athyrium falcatum Bedd., Ferns S. India t. 151. 1863; Mehra, Ferns Mussoorie: 20. 9 1939; FraserJenk., New Sp. Syndr. Indian Pteridol.: 58. 1997; Fraser-Jenkins, Taxon. Revis. Indian Subcontinental Pteridophytes, 601.2008; FraserJenk., D.R. Kandel, S. Pariyar, Ferns Fern-Allies
Nepal 1: 23. 2015. Patil et al., Field Guide Pterid. N. W. Ghats, 81. 2017.

Type: India, Tamil Nadu, Anamallaya (Annamalai). Asplenium drepanophyllum Baker, in Hooker \& Baker, Syn. Fil., ed. 2, 226. 1874.

Athyrium $x$ keralense Manickam \& Irudayaraj, Pterid. Fl. W. Ghats, S. India 238. 1992

Description: Plants 20-40 cm height, terrestrial, small-medium sized fern; rhizome 1-2 cm long, short, erect, caespitose, scaly; scales 2-7 mm long, liner-lanceolate, entire, yellow-brown, acuminate at apex, broad at base, margin entire; frond 19-38 cm long, 03-06 cm broad, monomorphic, pinnatepinnatifid, pale green-green; stipe 3-5 cm long, scaly, pale green at young, grooved; scales similar to the rhizome scales; lamina 16-33 cm long, 03-06 cm broad, dark green-pale green, unipennatepinnatifid, linear-lanceolate, apex acuminate, glabrous, glossy; rachis sparsely scaly, straminaceous, flat-round; pinnae 3-5 cm long, 1-2 cm broad, 12-25 pairs, subopposite-alternate, dentetly lobed, basal lobes auriculate, acute at apex, broad at base; veins distinct above and below, forked, reaching to the margin; sori 2.5-4 $\mathrm{mm}$ long, $0.5-1.5 \mathrm{~mm}$ broad, crescent or hook like, indusiate, median; indusia 2.5-4 mm long, 0.5-1.5 $\mathrm{mm}$ broad, thin membranaceus, yellow-brown, hook like, margin dentate, persistent; sporangia 200-600 $\mu \mathrm{m}$ in diameter, numerous, composed of 13-18 annular cells, sub-globose, brown; spores 40$60 \mu \mathrm{m}$ in diameter, monolete, plano-convex in lateral view and elliptic in polar view.

Distribution: India (Uttarakhand, Sikkim, Meghalaya, Tripura, Mizoram, Orissa, Parasnath Hills, Madhya Pradesh, Rajasthan, Maharashtra, Kerala), Nepal, Myanmar [Burma]. (Gujarat: Ahwa, Dang, Don, Dharampur, Kaprada, Mahal, Wilson Hills, Junagadh, Karjan dam, Dediapada and Sagai (common throughout Saurashtra, central and south Gujarat).

Phenology: Annual, Sterile phase: July-August; Fertile phase: August-November

Conservation status: Athyrium falcatum is known from central, south and Saurastra forest areas. This species is luxuriously growing in the Dangs, Valsad, Narmada and Junagadh a population of about 100-250 individuals were found and the area of occupancy (AOO) is $250 \mathrm{~km}^{2}$. Hence, according to IUCN categories and criteria (27), it is assessed as Least Concerned (LC) species.

Specimen Examined: INDIA, Gujarat, Navsari Dt., Vansada, 125 m, 01/12/2014, R.N. Kachhiyapatel \& K.S. Rajput, 126 (BARO); the Dangs Dt Kudkas, 152 m, 08/02/2015, R.N. Kachhiyapatel \& K.S. Rajput, 158 (BARO); Junagadh Dt., Girnar hills, $668 \mathrm{~m}$, 24/09/2017, R.N. Kachhiyapatel \& K.S. Rajput, 288 (BARO); Maharashtra, Satara Dt, Mahabaleshwar, alt. 1000 m., 13/10/1968, M. R. Almeida, 708 (BLAT); 17/07/1959, P. V. Bole, 1969 (BLAT); 13/08/1966, B. 

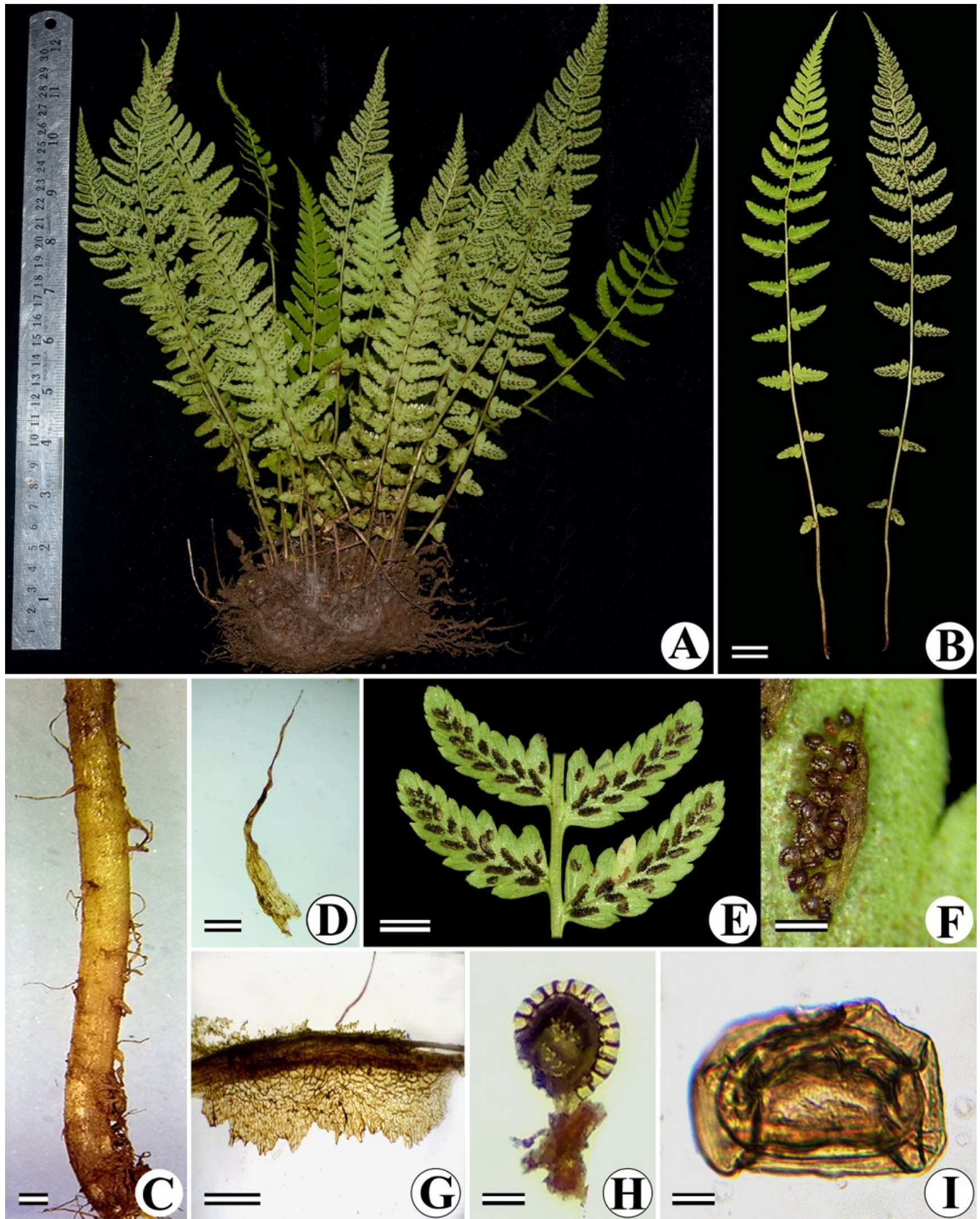

Fig. 1. Athyrium falcatum: A: Plant, B: Frond dorsal and ventral view, C: Stipe base showing scales, D: Stipe base scale, E: Parts of pinna showing arrangement of sori, F: Enlarged view of sorus showing sporangia and indusium, G: Indusium, H: Sporangium, I: Spore. Scale bar: $\mathbf{B}=20 \mathrm{~mm}, \mathbf{C}, \mathbf{F}=500 \mu \mathrm{m}, \mathbf{D}=2 \mathrm{~mm}, \mathbf{E}=6 \mathrm{~mm}, \mathbf{G}=300 \mu \mathrm{m}, \mathbf{H}=100 \mu \mathrm{m}, \mathbf{I}=10 \mu \mathrm{m}$.

M. Wadawa, 109426 (BLAT); Raigad Dt., Matheran, 20/10/1953, K. A. Patil (BLAT).

Athyrium micropterum Fraser-Jenk., New Sp. Syndr. Indian Pteridol. 58. 1997; Fraser-Jenkins, Taxon. Revis. Indian Subcontinental
Pteridophytes, 601. 2008; Fraser-Jenk., D.R. Kandel, S. Pariyar, Ferns Fern-Allies Nepal 1: 23. 2015.

Type: India, North-West Himalaya, Nainital Dt.

Description: Plants $15-40 \mathrm{~cm}$ in height, terrestrial, medium sized fern; rhizome 1-2 cm long, short, 
erect-suberect, scaly; scales 1.5-6 mm long, 1-3 mm broad, yellow-brown, liner-lanceolate, long acuminate apex, broad at base, margin entire; fronds 14-38 cm long, 3-6 cm broad, broadly lanceolate, pinnate-pinnatisect, acuminate, herbaceous, green-pale green; stipe 3-10 cm long, scaly, pale green-brown, grooved, shorter than lamina; scales same as like rhizome scales; lamina 11-28 cm long, 3-6 cm broad, pinnate-pinnatisect, broadly lanceolate, apex acute-acuminate, greenpale green, glossy, glabrous, lowest pinnae reduced; pinnae 3-6 cm long, 1-3 cm broad, 12-25 pairs, 20-30 pairs, ovate-deltoid or lanceolate, acute-subacute apex, broad at base, margin crenate, sessile to short stalked, suboppositealternate, deeply incised; veins forked, slightly distinct above and below; sori 2-4 mm long, 0.4-1.5 $\mathrm{mm}$ broad, indusiate, straight-hook like, along the veins, brown, median or sub-median; indusia 2-4 $\mathrm{mm}$ long, 0.4-1.5 mm broad, thin membranaceus, yellow-brown, straight-hook like, margin wavy or crenate; sporangia 200-500 $\mu \mathrm{m}$ in diameter, numerous, covered with 10-17 annular cells, subglobose, stalked; spores 40-60 $\mu \mathrm{m}$ in diameter, monolete, plano-convex-in lateral view and elliptic in polar view.

Distribution: India (Gujarat, Maharashtra). (Gujarat: The Dangs, Narmada, Tapi and Valsad).

Phenology: Annual, Sterile phase: July-August; Fertile phase: August-November

Ecology and conservation status: Athyrium micropterum is known from the Dangs forest areas. This species is luxuriously growing in the south Gujarat, a population of about $80-150$ individuals were found and the area of occupancy (AOO) is $250 \mathrm{~km}^{2}$. Hence, according to IUCN categories and criteria (27), it is assessed as Least Concerned (LC) species.

Specimen Examined: INDIA, Maharashtra, Satara Dt., Mahabaleshwar, alt 1200 m., 13/10/1968, M. R. Almeida, 711 (BLAT); Karnataka, North Kanara, 25/11/1950, Famandez, 1880 (BLAT); Andhra Pradesh, East Godavari Dt., Valamum, alt. 550 m., 23/12/1993, Mohanan, 170337 (MH); Gujarat, The Dangs Dt., Chinchli, $807 \mathrm{~m}$, 25/08/2017, R.N. Kachhiyapatel \& K.S. Rajput, 249 (BARO).

Athyrium hohenackerianum T. Moore, Index Fil. xlix 1857; Bedd., Ferns S. India t. 151. 1863; Bedd., Suppl. Ferns Brit. Ind.: 163. 1892; Manickam and Irudayaraj, Pterid. FI. W. Ghats, 233 - 234. 1992; Fraser-Jenkins, Taxon. Revis. Indian Subcontinental Pteridophytes, 601.2008. Patil et al., Field Guide Pterid. N. W. Ghats, 80. 2017.

Allantodia hohenackeriana Kunze, Farnkr.2. 63 t. 126. 1850.

Asplenium hohenackerianum Kunze in Bot. Zeitung (Berlin) 7: 771. 1849.
Type: India, Karnataka, Canara.

Description: Plants 10-35 cm in height, terrestrial, medium sized herb; rhizome 1-2 cm, sub-erecterect, densely scaly at apex; scales $2-6 \mathrm{~mm}$ long, 0.5-2 mm long, linear-lanceolate, concolor, apex acuminate, margin entire; frond pinnatifidbipinnate, elliptic lanceolate; stipe 03-10 cm long, densely scaly base, sparsely above; scales same as on the rhizome scales; lamina 06-23 x 3-6 cm, longer than stipe, pale green-green, ellipticlanceolate, apex long acuminate, lower pinnae reduced, rachis sparsely scaly; pinnae ovatelanceolate, apex acuminate, base broad, margin serrate, sessile to short stalked, oppositesubopposite; veins slightly distinct above and below, forked, reaching to the margin; sori 1.5-6 $\mathrm{mm}$ long, $0.6-2.5 \mathrm{~mm}$ broad, indusiate, straight or J-shaped, along the veins, median or sub-median; indusia 1.5-6 mm long, 0.6-2.5 mm broad, straight or J-shaped, thin, membranaceus, brown; sporangia $200-500 \mu \mathrm{m}$ in diameter, numerous, $10-$ 17 annular cells, sub-globose, brown; spores 45-65 $\mu \mathrm{m}$ in diameter, monolete, plano-convex to slightly concavo-convex in lateral view and elliptic in polar view.

Distribution: India (Andhra Pradesh, Chhattisgarh, Goa, Gujarat, Karnataka, Kerala, Madhya Pradesh, Maharashtra, Odisha, Rajasthan, Tamil Nadu), Sri Lanka. (Gujarat: common throughout Junagadh, Central and South Gujarat)

Phenology: Annuals, Sterile phase: June-July; Fertile phase: July-November

Ecology and conservation status: Athyrium hohenackerianum is known from Saurashtra, central and south Gujarat forest areas. This species is luxuriously growing in the central, Saurashtra and south Gujarat, a population of about 500-600 individuals were found and the area of occupancy (AOO) is $500 \mathrm{~km}^{2}$. Hence, according to IUCN categories and criteria (27), it is assessed as Least Concerned (LC) species.

Specimen Examined: INDIA, Maharashtra, Kolhapur Dt., Dajipur, 700 m., S. S. Patil, (SUK); Ratnagiri Dt., Dapoli, 100 m., M. V. Masal, (SUK); Satara Dt., Koynanagar, 800 m., B. V. Jadhav (SUK); Mahabaleshwar, alt. 1200 m, 06/09/1954, P. V. Bole, 1116 (BLAT); Gujarat, Narmada Dt., Sagai, 369 m, 19/09/2014, R.N. Kachhiyapatel \& K.S. Rajput, 64 (BARO); The Dangs Dt., Chinchli, 807 m, 25/08/2017, R.N. Kachhiyapatel \& K.S. Rajput, 251 (BARO).

Athyrium parasnathense (C.B. Clarke) Ching ex Mehra \& Bir, Res. Bull. Panjab Univ., Sci. 15: 141. 1964; Frazer-Jenkins, Taxon. Revis. Indian Subcontinental Pteridophytes., 208-209.2008. Patil et al., Field Guide Pterid. N. W. Ghats, 83. 2017.

Asplenium filix-femina (L.) Bernh.var. parasnathensis C.B.Clarke, Tr. Linn.Soc. II, 1: 493, 14 t. 61, C 21880. 

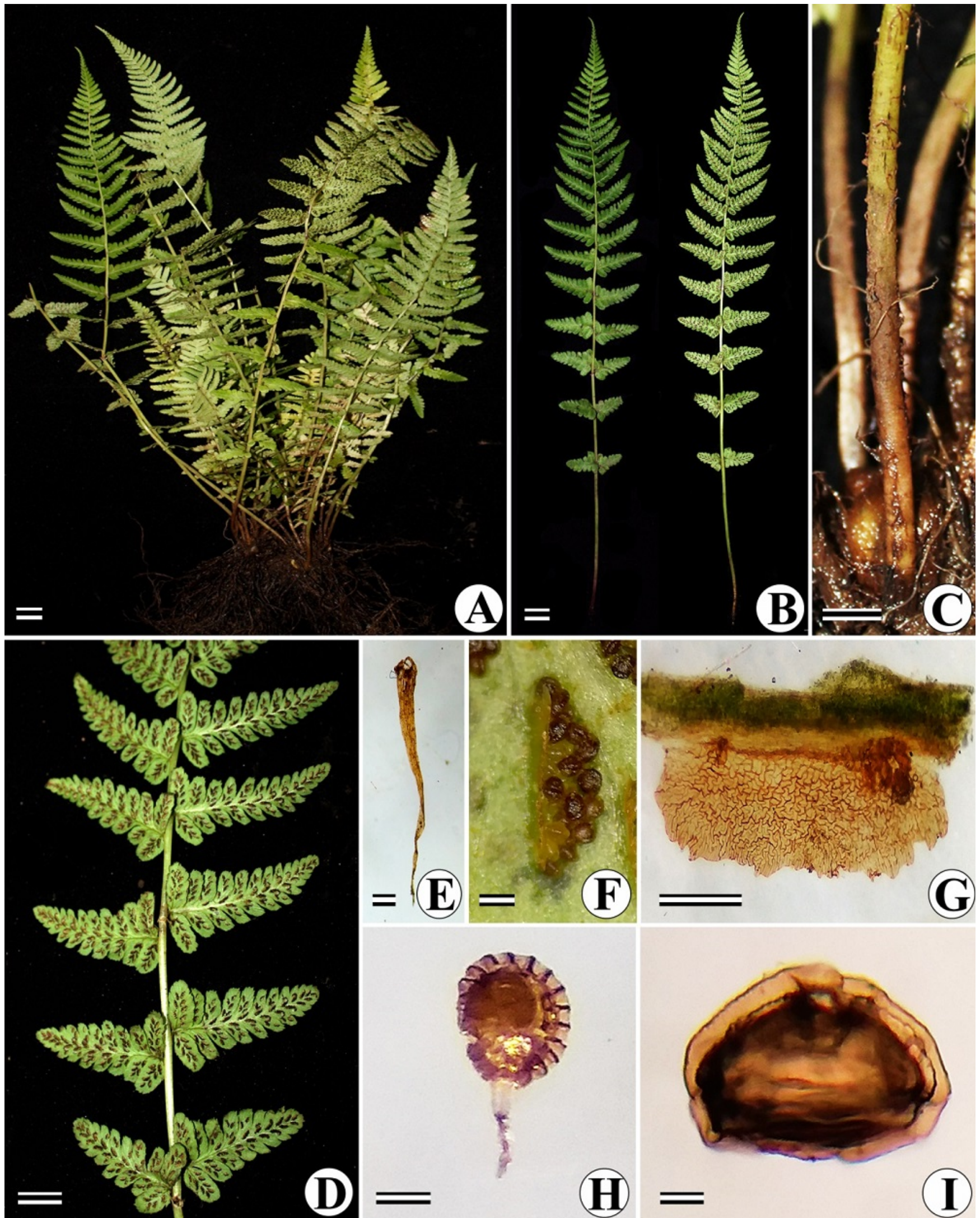

Fig. 2. Athyrium micropterum: A: Plant, B: Frond dorsal (left) and ventral (right) view, C: stipe base, D: Pinna, E: Stipe base scale, F: Sori, G: Indusium, H: Sporangium, I: Spore. Scale bar: A, B $=2 \mathrm{~cm}, \mathbf{C}=5 \mathrm{~mm}, \mathbf{D}=1 \mathrm{~cm}, \mathbf{E}=500 \mu \mathrm{m}, \mathbf{F}=\mathbf{5 0 0}$ $\mu \mathrm{m}, \mathbf{G}=\mathbf{5 0 0} \mu \mathrm{m}, \mathbf{H}=\mathbf{1 0 0} \mu \mathrm{m}, \mathbf{I}=10 \mu \mathrm{m}$.

Athyrium filix-femina (L.) Roth. var. parasnathensis (C.B.Clarke) Bedd., Handb. Ferns 16 Brit. India 170. 1883.

Type: India, Parasnath, Chota Nagpore.
Description: Plants 15-45 cm in height, terrestrial, medium sized fern; rhizome 1-2 cm, short erectsuberect, caespitose, scaly; scales 1-5 mm long, 0.5$2 \mathrm{~mm}$ broad, yellow-brown linear-lanceolate, acuminate at apex, broad at base, margin entire; frond 14-43 cm long, 3-7 cm broad, herbaceous, 

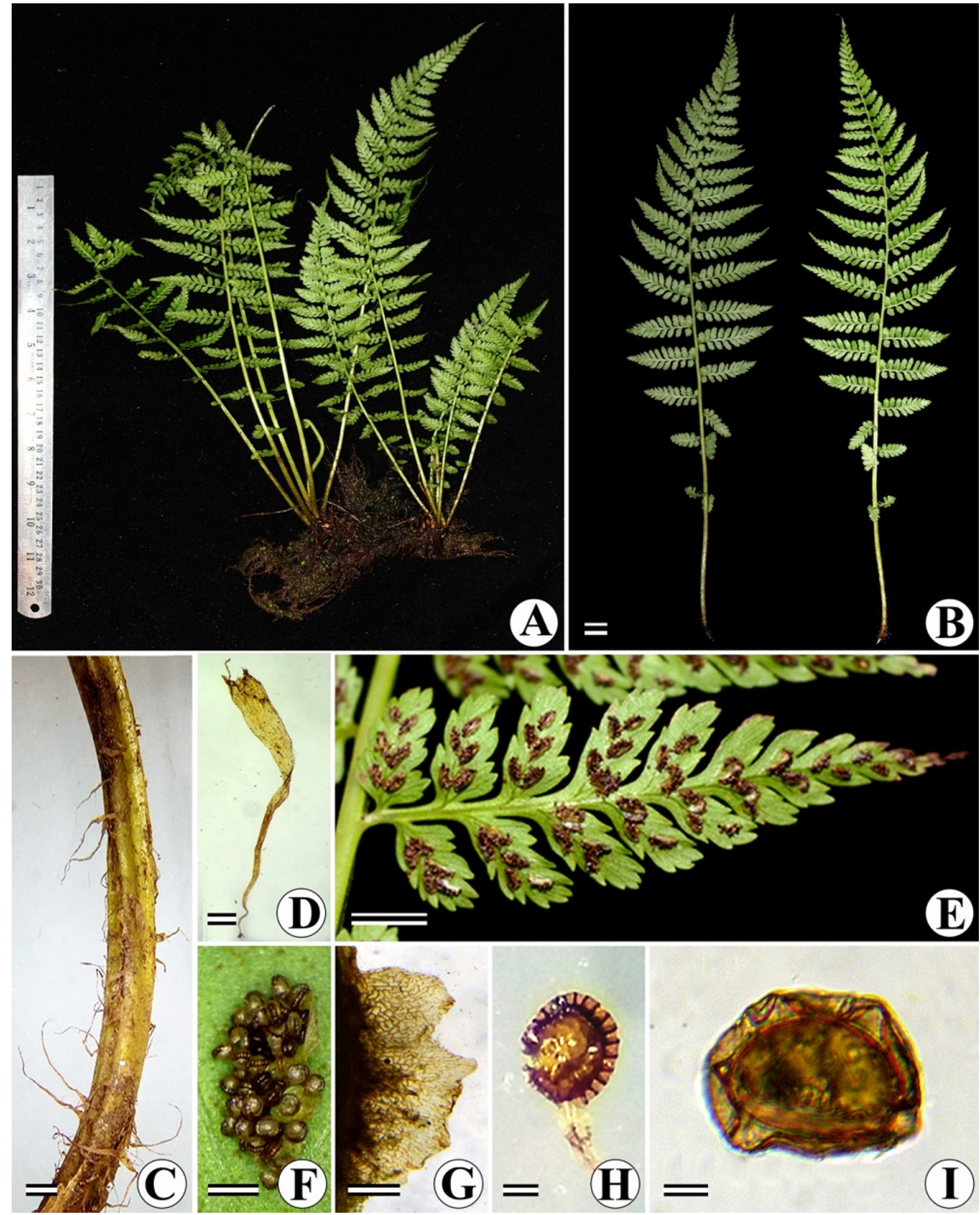

Fig. 3. Athyrium parasnathense: A: Plant, B: Frond dorsal (left) and ventral (right) view, C: Stipe base, D: Stipe base scale, E: Pinnae, F: Sori, G: Indusium, H: Sporangium, I: Spore. Scale bar: B = $2 \mathrm{~cm}, \mathbf{C}=2 \mathrm{~mm}, \mathbf{D}=500 \mu \mathrm{m}, \mathbf{E}=2.5 \mathrm{~mm}, \mathbf{F}=$ $500 \mu \mathrm{m}, \mathbf{G}=200 \mu \mathrm{m}, \mathbf{H}=\mathbf{1 0 0} \mu \mathrm{m}, \mathbf{I}=10 \mu \mathrm{m}$.

bipinnate-bipinnatifid, broadly lanceolate; stipe 3$10 \mathrm{~cm}$ long, pale green-brown, grooved, densely scaly at base; scales same as like rhizome scales; lamina 11-33 cm long, 3-7 cm broad, broadly lanceolate, apex acuminate, dark green-green, glabrous, glossy; pinnae 3-7 cm long, 2-3 cm broad,
15-25 pairs, deltoid-lanceolate, sessile to short stalked, subopposite-alternate, acuminate at apex, broad at base, margin crenate; veins forked, slightly distinct above and below; sori $1.5-5 \mathrm{~mm}$ long, 0.5-2 mm broad, indusiate, linear-hooked, two rows; indusia $1.5-5 \mathrm{~mm}$ long, $0.5-2 \mathrm{~mm}$ broad, 


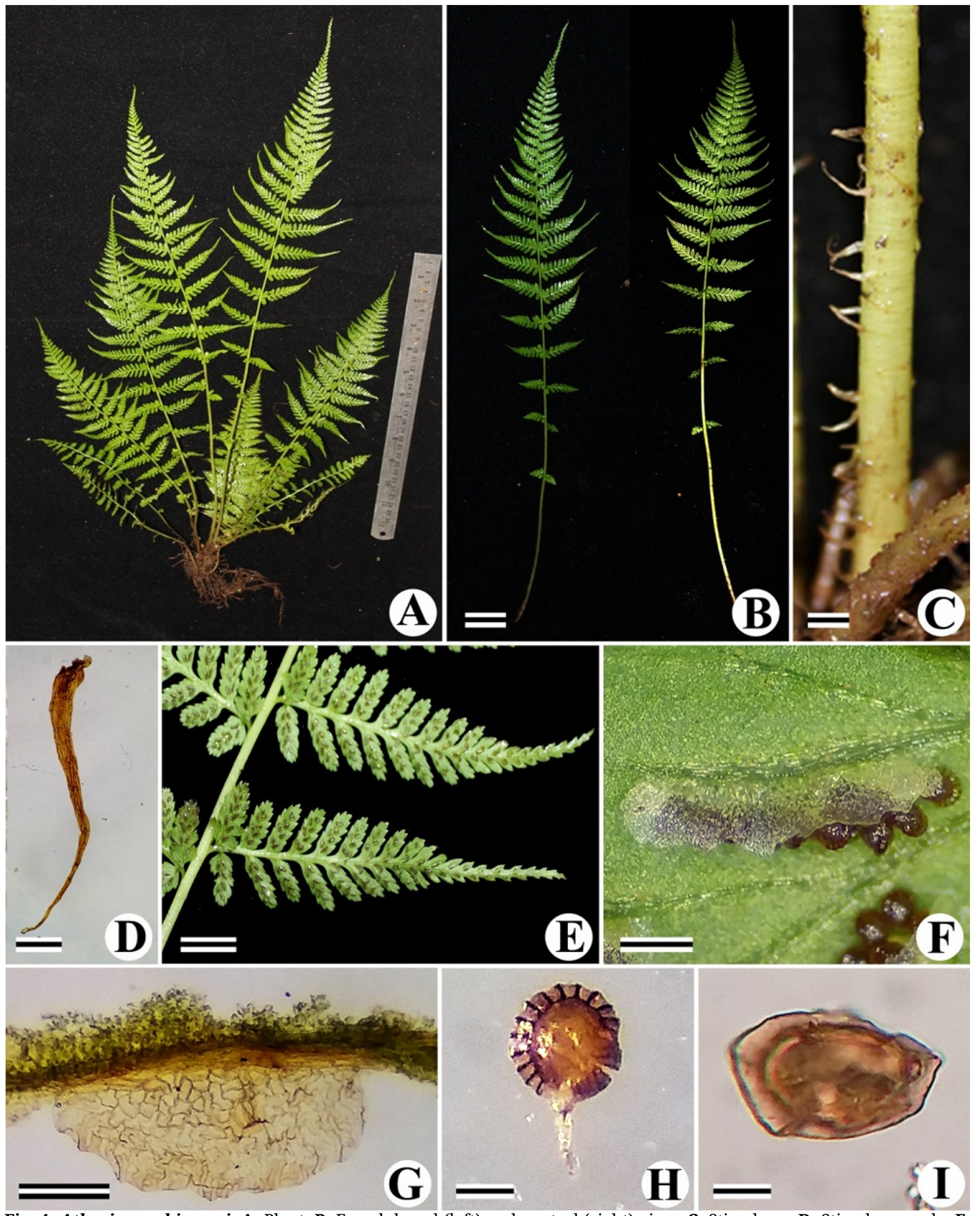

Fig. 4. Athyrium schimperi: A: Plant, B: Frond dorsal (left) and ventral (right) view, C: Stipe base, D: Stipe base scale, E: Pinna, F: Sori, G: Indusium, H: Sporangium, I: Spore. Scale bar: $\mathbf{B}=2 \mathrm{~cm}, \mathbf{C}=2 \mathrm{~mm}, \mathbf{D}=1 \mathrm{~cm}, \mathbf{E}=1 \mathrm{~cm}, \mathbf{F}=500 \mu \mathrm{m}, \mathbf{G}=$ $250 \mu \mathrm{m}, \mathbf{H}=125 \mu \mathrm{m}, \mathbf{I}=10 \mu \mathrm{m}$.

thin, membranaceus, linear or hooked, median or sub-median, persistent; sporangia 200-600 $\mu \mathrm{m}$, composed of 12-18 annular cells, sub-globose; spores $45-60 \mu \mathrm{m}$ in diameter, monolete, planoconvex to concavo-convex in lateral view and elliptic in polar view.
Distribution: India (Bihar, Gujarat, Karnataka, Maharashtra, Rajasthan, Sikkim, Tamil Nadu, Uttarakhand). (Gujarat: Ahwa, Dang, Don, Dharampur, Girnar, Kaprada, Mahal, Wilson Hills, Karjan dam, Dediapada, Sagai). 
Phenology: Annual, Sterile phase: July-August; Fertile phase: August-November.

Conservation status: Athyrium parasnathense is known from Valsad, Narmada, Dang, Shoolpaneswar, Ratanmahal and Junagadh forest areas. This species is luxuriously growing in the Saurashtra, central and south Gujarat, a population of about 100-350 individuals were found and the area of occupancy (AOO) is 250 $\mathrm{km}^{2}$. Hence, according to IUCN categories and criteria (27), it is assessed as Least Concerned (LC) species.

Specimen Examined: INDIA, Maharashtra, Satara Dt., Patan, 800 m, 20/08/2013, S. M. Patil \& M. M. Dongare, 1067 (SUK); Gujarat, Junagadh Dt., Girnar hills, 667 m, 24/09/2017, R.N. Kachhiyapatel \& K.S. Rajput, 290 (BARO); The Dangs Dt, Chinchli, 806 m, 25/08/2017, R.N. Kachhiyapatel \& K.S. Rajput, 250 (BARO).

Athyrium schimperi subsp. biserrulatum (Christ) Fraser-Jenk., New Sp. Syndrome Indian Pteridol. 60. 1997.

Type: China, Yunnan.

Asplenium filix-femina var. polyspora C.B.Clarke, Trans. Linn. Soc. London, 2 Bot., 1: 493,t. 61, f. 1. 1880.

Athyrium filix-femina var. polyspora (C.B.Clarke) Bedd., Handb. Ferns Brit. India 170. 1883.

Athyrium polysporum (C.B.Clarke) Ching ex Mehra \& Bir, Amer. Fern J. 50(4): 289. 1960.

Athyrium biserrulatum Christ, Bull. Acad. Int. Géogr. Bot., Mans 17: 135-136. 1907.

Description: Plants $20-45 \mathrm{~cm}$ in height, medium sized herb; rhizome 1-2 cm long, short creepingsuberect, scaly; scales 1-5 mm long, 0.5-2 mm borad, yellow-brown, liner-lanceolate, acuminate at apex, broad at base, margin entire; frond 19-43 cm long, 5-10 cm broad, monomorphic, pinnatebipinnate, ovate-lanceolate, herbaceous, dark green-green; stipe 4-10 cm long, shorter than lamina, densely scaly at base, sparsely above, grooved; scales same as like rhizome scales; lamina $15-33 \mathrm{~cm}$ long, $5-10 \mathrm{~cm}$ broad, ovate or broadly lanceolate, apex acuminate, lowest pinnae reduced, glabrous, glossy; pinnae 3-7 cm long, 1-3 $\mathrm{cm}$ broad, 15-25 pairs, ovate to lanceolate, long acuminate apex, cuneate base, margin crenate, short stalk-sessile, subopposite-alternate; veins forked, distinct above and below; sori $2-4.5 \mathrm{~mm}$ long, 0.5-2 mm broad, indusiate, linear or J-shaped, along the veins, median or sub-median; indusia 2$4.5 \mathrm{~mm}$ long, $0.5-2 \mathrm{~mm}$ broad, thin membranaceus, persistent; sporangia $200-600 \mu \mathrm{m}$ in diameter, numerous, composed of 10-18 annular cells, subglobose; spores 40-65 $\mu \mathrm{m}$ in diameter, monolete, plano-convex in lateral view and elliptic in polar view.
Distribution: Bhutan, China, India, Myanmar, Nepal, Pakistan, Tibet (Arunachal Pradesh, Gujarat, Himachal Pradesh, Jammu \& Kashmir, Madhya Pradesh, Nagaland, Rajasthan, Sikkim, Uttarakhand, West Bengal). (Gujarat: Dangs).

Phenology: Annual, Sterile phase: July-August; Fertile phase: August-November

Ecology and conservation status: Athyrium schimperi subsp. biserrulatum., is known only from the Dangs forest areas. A population of about 10-20 individuals were found and Area of occupancy (AOO) is $5 \mathrm{~km}^{2}$. However, other wildlife areas of the state are yet to be explored wholly and we presume that the species might be spread in similar ecological conditions. Thus, more floristic surveys are required to determine and document the full range of distribution of $A$. schimperi subsp. biserrulatum. Therefore, according to IUCN (27) criteria, at present this species is considered as data deficient (DD).

Specimen Examined: INDIA, Gujarat, The Dangs Dt., Borigaotha, $381 \mathrm{~m}, 05 / 10 / 2014, \quad$ R.N. Kachhiyapatel \& K.S. Rajput, 81 (BARO).

\section{Discussion}

First documented record of pteridophyte from Gujarat state (i.e. Ceratopteris thalictroides (L.) Brongn.) goes back to a century ago (9), but studies on this group became neglected thereafter. A. solenopteris is reported from Girnar Hills and other forest of the Saurashtra regions (11). Our repeated visits in last 6 years could not relocate the species from Girnar hills. Therefore, it appears that identification of this species might be mistaken for the species $A$. parasnathense (which we collected from Girnar hills). Moreover, the occurrence of $A$. solenopteris in Girnar is erroneous because it is endemic to south India and reported only at high altitude (i.e. above $1500 \mathrm{~m}$ ) (26). Nevertheless, Girnar hills are considered as one of the tallest hills from the state that has maximum altitude of $1000 \mathrm{~m}$.

In the present study, five species of Athyrium viz., $A$. hohenackerianum, A. falcatum, $A$. micropterum, A. parasnathense and A. schimperi subsp. biserrulatum were collected. Amongst these A. falcatum, A. micropterum, A. parasnathense and A. schimperi subsp. biserrulatum, are reporting as new distributional record for Gujarat state. Morphologically, A. falcatum and A. micropterum are closely related species. However, A. falcatum having pinnatifid lamina, suddenly reduced lower pinnae with auriculate pinnule whereas $A$. micropterum is having pinnatisect lamina, gradually reduced lower pinnae with or without auriculate pinnule. Similarly, $A$. hohenackerianum, A. parasnathense and A. schimperi subsp. biserrulatum are closely related species. However, A. hohenackerianum is having bipinnate lamina, densely scaly stipe and rachis, whereas $A$. 
parasnathense is having bipinnate to tripinnate lamina, sparsely scaly stipe only, pinnae with crenate pinnule and acute-obtuse apex and $A$. schimperi subsp. biserrulatum is having tripinnate lamina, sparsely scaly stipe only, pinnae with dentate pinnule and long acuminate apex.

\section{Acknowledgements}

Authors are thankful to Gujarat Biodiversity Board for financial support (during the year 2014-2015) forest officer for providing necessary permissions to visit different areas of the forest regions throughout the state. Thank are also due to Prof. S. P. Khullar for the confirmation of the identity and anonymous reviewers for their valuable suggestions on previous version of the manuscript.

\section{Authors contribution}

RNK and SMP collected the specimens from the field and wrote the initial draft of the manuscript, KSR supervised the project while revision of the manuscript is done by KSR and VMR. All the authors approved the final manuscript.

\section{Competing interest}

Authors declare that we have no competing interest.

\section{References}

1. Roth AW. Tentamen Florae Germanicae. 1800; 3(1): 31, 58-59.

2. Christensen C. Index filicum. Copenhagen: Hagerup. 1906.

3. Copeland EB. Genera Filicum. Chronica Botanica Co., Waltham. 1947.

4. Shieh WC, Devol CE, Kuo CM. Athyriaceae. In: T.C. Huang et al. (eds.), Flora of Taiwan, ed. 2, 1994; 1: 414-448. Editorial Committee, Department of Botany, National Taiwan University, Taipei, Taiwan.

5. Fraser-Jenkins CR. Woodsiaceae. In: M. Shaffer-Fehre (ed.), Flora of Ceylon 15B. Ferns and fern allies. 2006; 532576. Science Publishers. Enfield, NH, USA.

6. PPGI. A community-derived classification for extant lycophytes and ferns. J. Syst. Evol. 2016; 54 (6): 563-603. https://doi.org/10.1111/jse.12229

7. Wei R, Ebihara A, Zhu YM, Zhao CF, Hennequin S, Zhang XC. A total-evidence phylogeny of the lady fern genus Athyrium Roth (Athyriaceae) with a new infrageneric classification. Mol. Phyl. Evol. 2018; 119:25-36. https://doi.org/10.1016/j.ympev.2017.10.019

8. Fraser-Jenkins CR, Gandhi KN, Kholia BS. An Annotated checklist of Indian Pteridophytes Part - 2. 2018. (Woodsiaceae to Dryopteridaceae). Bishen Singh Mahendra Pal Singh, Dehra Dun, India.

9. Saxton WT, Sedgwick LJ. Plants of northern Gujarat. Rec. Bot. Survey, Indi. 1918; 6: 221-223.

10. Mahabale TS. Cultural Behaviour of Prothalli of Stenchlaena palustris, Ceratopteris thalictroides and Athyrium hohenackerianum. Plant and Organ Culture,
Symp. Published Int. Soc. Plant Morphol. 1963; 382-289. https://doi.org/10.1086/335486

11. Nayar BK, Devi S. Spore morphology of Indian ferns I. Aspidiaceae. Grana Paly. 1964; 5:1, 80-120. https://doi.org/ $\underline{10.1080 / 00173136409429131}$

12. Kachhiyapatel RN, Singh AP, Raole VM, Rajput KS. Distribution and occurrence of some pteridophytes in Gujarat: A new record for the state. J. of the Indian Bot. Soc. 2015; 94(3\&4):236-244.

13. Kachhiyapatel RN, Patel SK, Rajput KS. Reporting Adiantum capillus-veneris $\mathrm{L}$. and Thelypteris prolifera (Retz.) C.F. Reed as new record for Gujarat state together with their molecular identity. Indian Fern J. 2016; 33:6980 .

14. Patil SM, Kachhiyapatel RN, Patel RS, Rajput KS Ophioglossum gujaratense, a new species from Gujarat State, India. Phytotaxa. 2018; 351(4):273-280. https://doi.org/10.11646/phytotaxa.351.4.3

15. Kachhiyapatel RN, Patil SM, Patel SK, Rajput KS. Genus Ophioglossum L., from Western Part of India with Special Reference to Gujarat State. Not. Sci. Bio. 2018; 10(3):373378. https://doi.org/10.15835/nsb10310243

16. Patel SK, Kachhiyapatel RN, Singh AP, Rajput KS. Status of Isoetes coromandeliana L. f. and Equisetum debile Roxb. ex Voucher in Gujarat State, Western India. Not. Sci. Bio. 2015; 7(4):441-443. https://doi.org/10.15835/nsb.7.4.9696

17. Rajput KS, Kachhiyapatel RN, Patel SK, Raole VM. Assessment of pteridophyte diversity and their status in Gujarat state, western India. Plant Sci. Today. 2016; 3(4):337-348. https://doi.org/10.14719/pst.2016.3.4.235

18. Blatter E, d'Almeida JF. The ferns of bombay. 1922. Diocesan press, Madras. https://doi.org/10.5962/bhl.title.55679

19. Kshirsagar MK, Mehta AR. Survey of ferns in Gujarat state (India) for presence of antimicrobial substances of ferns. Planta medica. 1972; 22(08) 386-390. https://doi.org/ 10.1055/s-0028-1099623

20. GEC, (Gujarat Ecological Commission). Biological diversity of Gujarat: Current knowledge. 1996. Technical report, GERI Campus, Gandhinagar, Gujarat.

21. Beddome RH. The ferns of southern India. Being descriptions and plates of the ferns of the Madras presidency. 1873. Madras:Higginbotham and co.

22. Beddome RH. Supplement to the ferns of South India and British India. 1876. Madras: Gantz Brothers, at the Adelphi press, 7 \& 8 mount road.

23. Beddome RH. Handbook to the ferns of British India Ceylon and the Malay Peninsula with supplement. 1892 Calcutta Thacker, Spink, and Co. https://doi.org/10.5962/bhl.title.49551

24. Vasudeva SM, Bir SS. Pteridophytic flora of Pachmarhi hills, Central India-III* (Fern families:GleicheniaceaeAthyriaceae). Indian Fern J. 1993; 10:113-138.

25. Fraser-Jenkins CR. New species syndrome in Indian pteridology and the ferns of Nepal. 1997. International Book Distributors, Dehra Dun, India.

26. Fraser-Jenkins CR. Taxonomic revision of three hundred Indian subcontinental pteridophytes with a revised censuslist. 2008. Bishen shing mahendra pal singh (Dehra Dun).

27. IUCN. Guidelines for Using the IUCN Red List Categories and Criteria. Ver. 12. 2017-1. Prepared by the Standards and Petitions Subcommittee. 